\title{
DETERMINATION OF RELATIONSHIP BETWEEN LAND SURFACE TEMPERATURE AND DIFFERENT LAND USE BY CHAID ANALYSIS
}

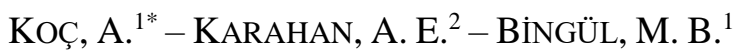 \\ ${ }^{1}$ Igdir University, Faculty of Agriculture, Department of Landscape Architecture \\ 76000 Igdir, Turkey \\ ${ }^{2}$ Igdir University, Faculty of Agriculture, Department of Zootechnic, 76000 Igdir, Turkey \\ *Corresponding author \\ e-mail:ahmetkoc0625@hotmail.com
}

(Received 22 $2^{\text {nd }}$ Feb 2019; accepted 29 $9^{\text {th }}$ Mar 2019)

\begin{abstract}
The increasing average air temperatures and the change of climate elements pose negative threats to human and its life. Human beings develop different methods and plans to eliminate and minimize the threats that occur. Satellite imagery is the tool of these methods and plans. Through existing satellite imagery, land surface temperatures and land uses are determined by remote sensing methods to provide sustainable planning. Surface temperatures of the land are such a parameter that concerns the climate, fauna, flora and interaction of human beings with the environment. This study aimed to establish the bond between the surface temperature of the land and the different land uses. The data was collected from Erzurum province, which is located in Turkey, with a surface area of $25066 \mathrm{~km}^{2}$. Thermal Band data obtained from four different dates which represents the four seasons and Coordination of Information on the Environment (CORINE) Land Cover (CLC) maps were digitized and interpreted statistically in Geographic Information Systems (GIS) package program. The results showed that forest areas $12.2^{\circ} \mathrm{C}$, water surfaces $13.8^{\circ} \mathrm{C}$, agricultural areas $17.9^{\circ} \mathrm{C}$, open areas $15.7^{\circ} \mathrm{C}$ and residential areas $18.7^{\circ} \mathrm{C}$ has average surface temperature values. Statistically, the bonds between land uses and other variables were evaluated using Chi-square Automatic Interaction Detector (CHAID) analysis. As a result, this study will contribute planners and decision makers develop climate-sensitive strategies and policies regarding basin planning and urban planning.
\end{abstract}

Keywords: thermal band, CORINE, CHAID analysis, surface temperature, land use, Turkey

\section{Introduction}

Scientifically proven that temperatures have increased over the current century and this increase will continue in the future (Becker et al., 2012; Fearnside, 2015). In climate change scenarios for the years between 1990-2050 some hypotheses were developed and according to these hypotheses, it is asserted that the temperature will increase by $2-2.9^{\circ} \mathrm{C}$ on a global basis (van der Knaap et al., 2018). Climate change causes increased temperature, irregular precipitation and therefore a significant change in the climate cycle (Alexander et al., 2006; van Haren et al., 2013; Rajczak and Schar, 2017). Climate change with increased temperature forces people to live in places close to different land use areas in order to sustain their comfortable lives. The differences in land uses arise as a result of a mechanism created by the human and natural processes. Land changes over existing ecosystems has led to the emergence of surface temperature differences (Arnfield, 2003; Wu et al., 2012; Gonzalez et al., 2013). It has also caused a decrease in water quality and quantity due to varying climate in different land uses (Felzer, 2012; Tong et al., 2012; Seung-Hwan et al., 2013; El-Khoury et al., 2015). Recently, scientists are working on large areas with thermal band analyses 
based on remote sensing methods, while generating future scenarios and hypotheses (Zhan et al., 2011; Chen et al., 2014; Cho et al., 2018). Monitoring global climate change and its impacts with remote sensing methods has made it possible to make urban climate assessments (Zhang et al., 2004; Weng, 2009; Masiello et al., 2015). At the same time, the surface temperature, which is the basic climate parameter, has a great importance. Surface temperature is one of the physical parameters of land surface processes from local scale to global scale (Li et al., 2013). The surface temperature, surface radiation, and therefore the energy, has a great proposition in terms of its optimal use (Voogt and Oke, 2003; Yang et al., 2012; Feng and Myint, 2016). It is also stated in previous studies that the effect of surface temperature that directly influences the air temperature as a result of the division of anthropogenic effects is of great importance at spatial scale (Chrysoulakis et al., 2013; Song et al., 2017). Given the importance of surface temperature in terms of location and environmental sciences, temporal change provides a remarkable source of information ( $\mathrm{Li}$ et al., 2013). The surface temperature of the land represents a unit of climate change from the "Land Surface Temperature" (LST) remote sensing platforms (Gallego-Elvira et al., 2016; Rosas et al., 2017). To monitor the effects of global warming and climate change, it is necessary to make assessments in different land uses (Zhang et al., 2004; Masiello et al., 2015; Blasi et al., 2016).

In thermal satellites, land surface temperature measurements are somewhat difficult because satellites are influenced by both surface temperatures and atmospheric conditions (Prata et al., 1995). In order to avoid measurement constraints, it is possible to achieve atmospheric correction of the thermal data with well developed split window approaches using two TIR bands (Becker and Li, 1990). With a swath width of 2,330 km, The Moderate Resolution Imaging Spectroradiometer (MODIS) satellite module is capable of displaying every single point in the world every day or two with the help of 36 different spectral bands (Xia et al., 2018). Indeed, the MODIS satellite provides a choice for scientific studies in order to be able to work on a regional scale between land uses and surface temperature (Justice et al., 2002; Jacob et al., 2004). Using MODIS satellite data, the linkages between the seasonal temperature distributions of the areas and land uses within the study area boundaries were investigated. The main purpose of this study is to investigate the compatibility of the thermal comfort with the environment in different land uses. As study site, Erzurum Province, which accommodates 3 different basin areas and topographic structure ranging from $850-3500 \mathrm{~m}$, were selected. The results of the study will contribute planners and decision makers develop climate-sensitive strategies and policies regarding basin planning and urban planning.

\section{Material and Method}

Erzurum Province (approximately $25066 \mathrm{~km}^{2}, 40^{\circ} 15^{\prime \prime}-42^{\circ} 35^{\prime \prime} \mathrm{E}, 40^{\circ} 57^{\prime \prime}-39^{\circ} 10^{\prime \prime} \mathrm{N}$ ), which is located in Turkey, has a terrestrial climate. The average air temperature is $-7^{\circ} \mathrm{C}$ in January and $16.2^{\circ} \mathrm{C}$ in July. The average annual air temperature is $6.1^{\circ} \mathrm{C}$ and is below $-4.4^{\circ} \mathrm{C}$ from December to March. The average annual precipitation is $39.6 \mathrm{~mm}$, and the wet season is from April to January. Short summer and a long winter lead to a high thermal exposure for the city. Land topography in the study area is constantly changing. Topography, which varies from $3200 \mathrm{~m}$ to $780 \mathrm{~m}$, supports the formation of different climatic areas (Figure 1). 


\section{Land Use Classification of the Study Site}

The land use classification map of the study area was created as a result of the digitization of Corine level 3 1/25000 scaled raster maps which obtained from Provincial Directorate of Agriculture (Figure 2). There are 44 different category of Corine level 3 in Turkey (İT, 2004). Within the Erzurum province, there are 27 subcategories regarding to Corine level 3 . These categories are reduced by simplifying to level 1 (Yildiz et al., 2018). As a result of this classification, the study site is divided into 5 different categories, including open areas, agricultural areas, forests, water surfaces and residential areas (Figure 2).

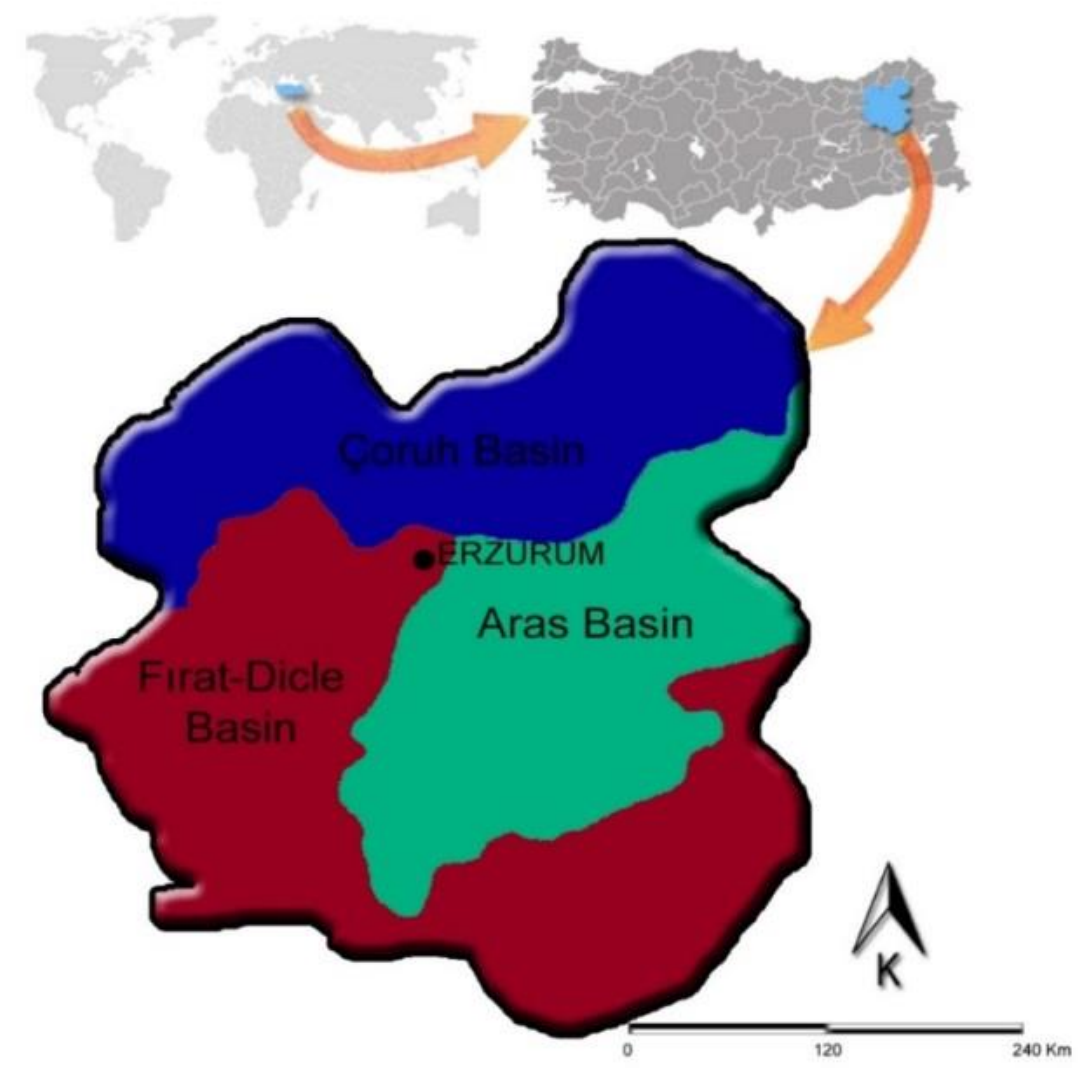

Figure 1. The study site

\section{Thermal Satellite Images of the Study Site}

In the lower scale land surface temperature (LST) studies, researchers mostly use Landsat-7 and Landsat-8 thermal sensors (Mallick et al., 2008; Mallick et al., 2012; Yildiz et al., 2018). Although the Landsat data sets that provide highly reliable and precise results in lower scale studies have also used in the upper scale, some problems can occur due to the area occupied by each raster data set and the bandwidth. For instance, in the upper scale LST studies if you use Landsat data set, four or five raster images are needed to define your study site, but MODIS data set, one raster image is enough to define it. This is one of the reasons why we used the MODIS data set in this study. Another reason why we preferred the MODIS satellite, because the satellite completes its tour around the globe in one day, offering unique opportunities for users. 


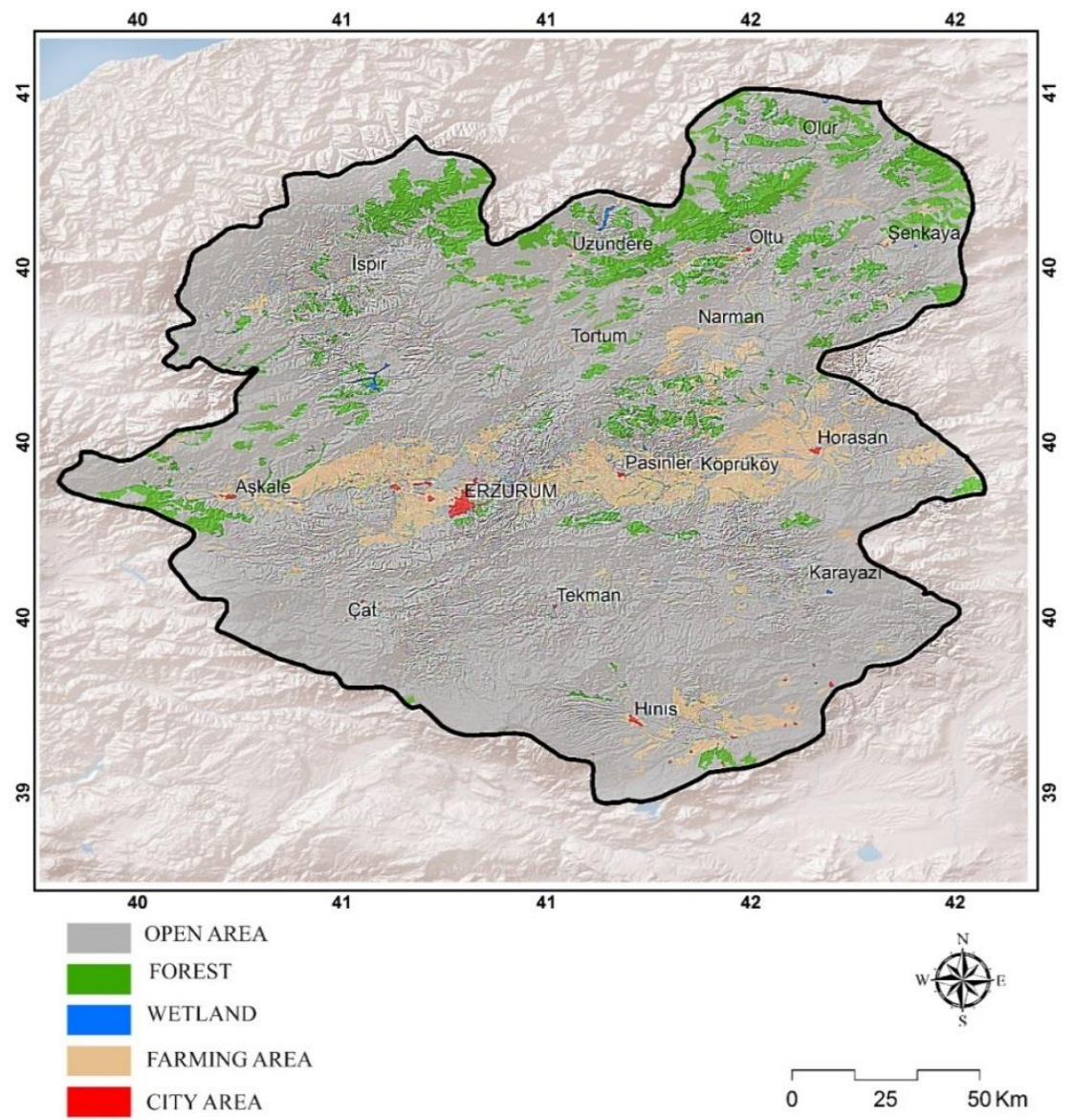

Figure 2. Land use classification map of the study site

Thermal images for the study site have $1000 \mathrm{~m}$ spatial resolution and $21^{\text {st }}$ Band of MODIS satellite thermal infra-red data, 3,929 $\mu \mathrm{m}-3,989 \mu \mathrm{m}$, is used. In order to verify the surface temperature of the radiation intensity of the obtained data the Stefan-Boltzmann law was used (Montvay and Pietarinen, 1982; Narimanov and Smolyaninov, 2012; Rosas et al., 2017).

$$
T s=\sqrt[4]{\frac{T_{m}^{4}-(1-\epsilon) T_{s k y}^{4}}{\epsilon}}
$$

where

- $T_{m=}$ Surface temperature measured by radiometer.

- $T s=$ Surface temperature.

- $T_{s k y}=$ Sky temperature.

- $\epsilon=$ Surface emissivity.

Thermal infra-red images of the validated data were obtained by processing the ARC-G1s 10.2 Package program with a controlled classification method (Eastman, 2001) (Figure 3). Pixel spacing has been utilized when controlled classification is performed. The 255-bit RGB-size thermal image indicates the highest bit range of 
350 Kelvin degrees and 200 Kelvin degrees at the lowest 1-bit size. The following equation has been used to convert the RGB image to degrees Celsius. Data from the $2^{\text {nd }}$ band of the MODIS satellite were digitized with the following formula (https://worldview.earthdata.nasa.gov).

$$
{ }^{\circ} \mathrm{C}=\left[T_{\min }+\left(\frac{T_{\max }-T_{\min }}{255}\right) x R G B\right]-273.15
$$

where

- ${ }^{\circ} \mathrm{C}$ : Celsius.

- RGB: Value at point of measurement.

- $T_{\max }=$ Maximum Kelvin degree indicated by thermal band.

- $T_{\min }=$ The minimum Kelvin degree indicated by thermal band.

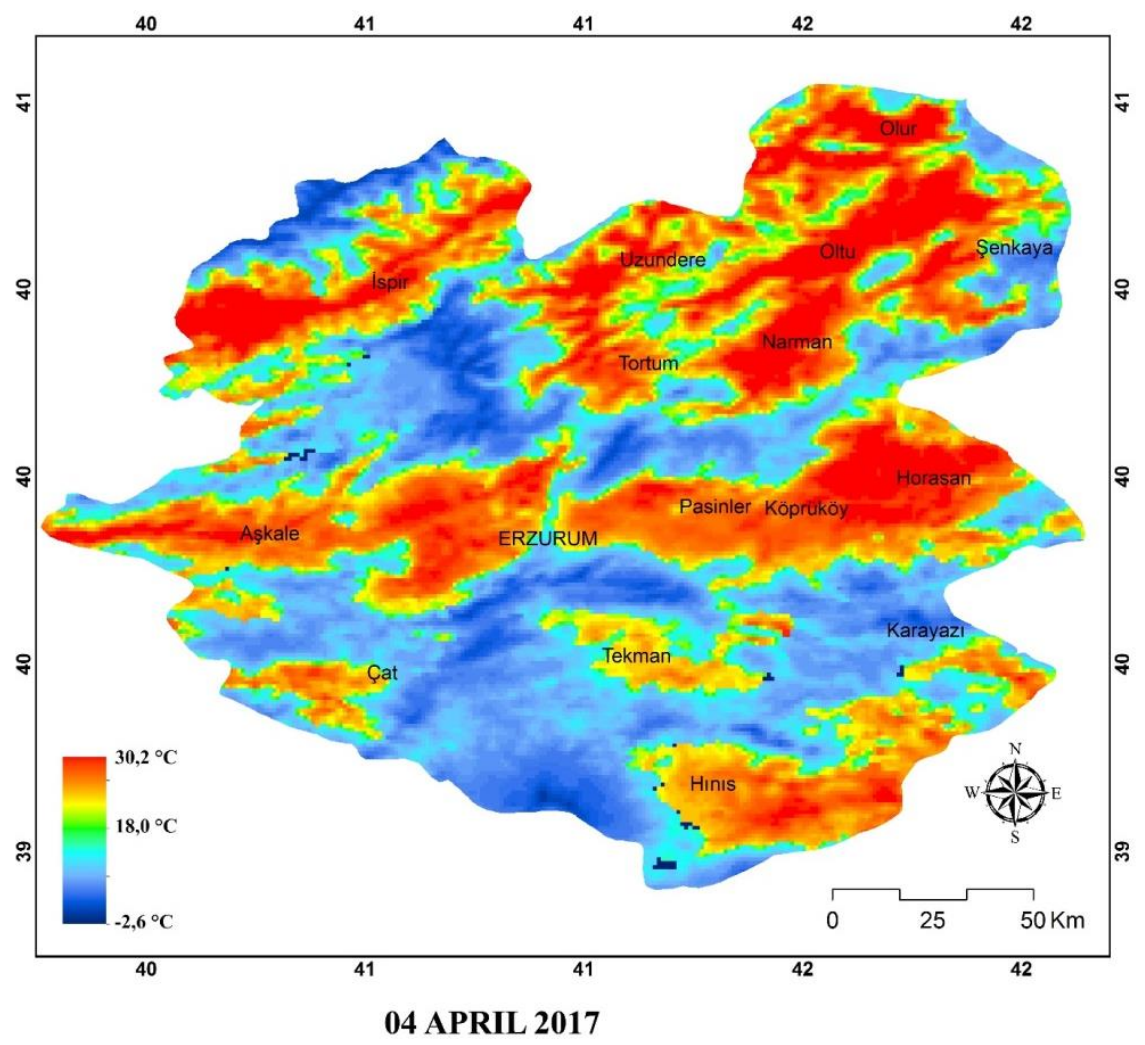

Figure 3. Thermal Band Analysis of the study area on 4 April 2017

In this study, four different dates were selected for thermal data. The selected dates are equal to the average temperatures of the seasons in which they belong. The average temperatures of the winter, spring, summer and autumn seasons were obtained from the General Directorate of Meteorology Affairs. The thermal data set of each day was obtained from the MODIS satellite.

Landsat satellites pass through a point every 16-days (Feng et al., 2013). The thermal band analyses of the MODIS satellite are obtained on a daily basis, especially on land surface temperatures (LST) (Rawat et al., 2018). The data obtained from the MODIS satellite is not suitable for use at lower scales due to the resolution, but in the upper 
scales or in the wide range of fields, the MODIS satellite offers different opportunities in terms of LST (Rawat et al., 2018). Our study was conducted in a large area of approximately $25,066 \mathrm{~km}^{2}$ which is categorized as upper scale class

Three different watershed structures were taken into account when receiving thermal temperature data for different land classification in the study site. Thermal temperature values were obtained from 10 different locations of each different land use. Besides, 4 different time intervals were determined to be compatible with the study on a seasonal basis. These time intervals were matched with data from the General Directorate of State Meteorology. As a result of this pairing, each date carries similar qualities with the average temperature of the season.

\section{Statistical Analysis of the Data of the Study Site}

Decision trees are a widely used method for data mining and machine learning. The Chaid analysis technique is a decision tree algorithm that summarizes the relationships of arguments with each other and the dependent variable in a tree-shaped diagram. In the tree model, decision-making points are called nodes. In this model, the diagram begins to branch with the root node, which encompasses all relationships and is the most complex node. After that, the arguments are separated into the child nodes, which are heterogeneous among each other, homogeneous each time. When adequate homogeneity is ensured, the division stops, and these nodes are called terminal nodes. In the Chaid analysis, which is a Non-parametric test, dependent and independent variables can be continuous, discrete, or categorical and does not require preconditions and assumptions, such as normalcy and linearity required by parametric tests. When the tree diagram is divided into nodes, if the dependent variable is categorical, the chi-square statistic or if it is continuous the F-test are used (Akin et al., 2017). The reason for the selection of Chaid analysis in this study is that two of the independent variables are categorical (land use and month) and one is a constant variable (altitude). The determination coefficient $\left(\mathrm{R}^{2}\right)$ between the observed temperature values and the expected temperature values was calculated as 0.82. Minimum parental node count 20, child node count 10, maximum tree depth set as 3 and statistical analysis was done in SPSS 17.0 package program.

$$
R^{2}(\%)=\left[1-\frac{\sum_{i=1}^{n}\left(Y_{i}-\hat{Y}_{i}\right)^{2}}{\sum_{i=1}^{n}\left(Y_{i}-P\right)^{2}}\right] * 100
$$

\section{Results}

The thermal band Analysis taken on April 4, 2017 showed that open areas have minimum $-1.15^{\circ} \mathrm{C}$ maximum is $32.4^{\circ} \mathrm{C}$ surface temperature and the surface temperature difference $33.6^{\circ} \mathrm{C}$ is measured. Forests surface temperature is minimum $1.2^{\circ} \mathrm{C}$, maximum of $18.0^{\circ} \mathrm{C}$ and the temperature difference is $16.8^{\circ} \mathrm{C}$. For water surfaces the temperature minimum $1.2^{\circ} \mathrm{C}$, maximum $29.4^{\circ} \mathrm{C}$ and the difference is $28.2^{\circ} \mathrm{C}$. Surface temperature parameters for agricultural land use minimum $4.2^{\circ} \mathrm{C}$, maximum of $27.6^{\circ} \mathrm{C}$ and the temperature difference is $23.4^{\circ} \mathrm{C}$. Residential areas; the surface temperature is similar to other land uses; minimum $2.4^{\circ} \mathrm{C}$, maximum $29.4^{\circ} \mathrm{C}$ and the difference is $27^{\circ} \mathrm{C}$ (Table 1 and Figure 3). If we handle the study site on the basin scale, it is determined that the surface temperature is colder than the Çoruh Basin on the east of the Araz Basin and the Euphrates-Tigris Basin on April 4. 
Table 1. The values of thermal band analysis results of the study area on 4 April 2017

\begin{tabular}{c|c|c|c|c|c}
\hline Points & $\begin{array}{c}\text { Open Areas } \\
\left({ }^{\circ} \mathbf{C}\right)\end{array}$ & $\begin{array}{c}\text { Forests } \\
\left({ }^{\circ} \mathbf{C}\right)\end{array}$ & $\begin{array}{c}\text { Water Surfaces } \\
\left({ }^{\circ} \mathbf{C}\right)\end{array}$ & $\begin{array}{c}\text { Agricultural Areas } \\
\left({ }^{\circ} \mathbf{C}\right)\end{array}$ & $\begin{array}{c}\text { Residentian Areas } \\
\left({ }^{\circ} \mathbf{C}\right)\end{array}$ \\
\hline $\mathbf{1}$ & 21.0 & 7.2 & 1.2 & 22.8 & 20.4 \\
$\mathbf{2}$ & 4.2 & 15.6 & 18.6 & 25.8 & 20.8 \\
$\mathbf{3}$ & 16.8 & 1.25 & 3.0 & 4.2 & 25.8 \\
$\mathbf{4}$ & 8.4 & 14.4 & 1.8 & 25.2 & 2.4 \\
$\mathbf{5}$ & 7.2 & 4.2 & 29.4 & 20.4 & 29.4 \\
$\mathbf{6}$ & 32.4 & 6.0 & 19.2 & 22.8 & 26.4 \\
$\mathbf{7}$ & -1.1 & 10.2 & 1.2 & 4.2 & 22.8 \\
$\mathbf{8}$ & 5.4 & 18.0 & 6.0 & 15.0 & 25.8 \\
$\mathbf{9}$ & 6.6 & 7.8 & 21.0 & 27.6 & 18.6 \\
$\mathbf{1 0}$ & 14.4 & 6.1 & 14.4 & 21.6 & 10.8 \\
\hline
\end{tabular}

For the thermal band analysis taken on June 17 2017, when we examined in terms of the land uses, open area sampling points are maximum $30.6^{\circ} \mathrm{C}$, minimum $20.4^{\circ} \mathrm{C}$ and the difference is $10.2^{\circ} \mathrm{C}$. Forests minimum surface temperature is $18.0^{\circ} \mathrm{C}$, maximum of $27.6^{\circ} \mathrm{C}$ and the temperature difference is $9.6^{\circ} \mathrm{C}$. The temperature of the water surfaces is minimum $-3.5^{\circ} \mathrm{C}$, maximum $31.8^{\circ} \mathrm{C}$ and the total difference is $35.4^{\circ} \mathrm{C}$. In terms of agricultural areas are observed at a minimum temperature of $24.6^{\circ} \mathrm{C}$, while the temperature difference is observed at a maximum of $33.0^{\circ} \mathrm{C}$. The total temperature difference in agricultural land use is $8.4^{\circ} \mathrm{C}$. Similarly, the surface temperature observed at minimum $24.6^{\circ} \mathrm{C}$ in the residential area is $31.2^{\circ} \mathrm{C}$ and the difference is $6.6^{\circ} \mathrm{C}$ (Table 2 and Figure 4). On the basin scale, the surface temperature of the Aras Basin is seen to be significantly higher than the other 2 basins. In some points, air corridors in the form of deep canyons in basin bases cause wind mobility to cool down the surface cover and this is an evident in the north-west strip of Aras Basin and in the northern of the Çoruh Basin.

Table 2. The values of thermal band analysis results of the study area on June 172017

\begin{tabular}{c|c|c|c|c|c}
\hline Points & $\begin{array}{c}\text { Open Spaces } \\
\left({ }^{\circ} \mathbf{C}\right)\end{array}$ & $\begin{array}{c}\text { Forests } \\
\left({ }^{\circ} \mathbf{C}\right)\end{array}$ & $\begin{array}{c}\text { Water Surfaces } \\
\left({ }^{\circ} \mathbf{C}\right)\end{array}$ & $\begin{array}{c}\text { Agricultural Areas } \\
\left({ }^{\circ} \mathbf{C}\right)\end{array}$ & $\begin{array}{c}\text { Residential Areas } \\
\left({ }^{\circ} \mathbf{C}\right)\end{array}$ \\
\hline $\mathbf{1}$ & 24.6 & 18.6 & 20.4 & 27.0 & 27.6 \\
$\mathbf{2}$ & 20.4 & 18.0 & 21.6 & 28.2 & 31.2 \\
$\mathbf{3}$ & 20.4 & 20.4 & 21.0 & 25.2 & 30.0 \\
$\mathbf{4}$ & 27.6 & 21.6 & -3.5 & 25.8 & 27.6 \\
$\mathbf{5}$ & 30.6 & 21.6 & 31.8 & 25.8 & 28.2 \\
$\mathbf{6}$ & 26.4 & 21.6 & 25.2 & 30.0 & 24.6 \\
$\mathbf{7}$ & 23.4 & 18.0 & 20.4 & 24.6 & 29.4 \\
$\mathbf{8}$ & 30.0 & 27.6 & 21.0 & 25.8 & 25.8 \\
$\mathbf{9}$ & 25.2 & 23.4 & 29.4 & 24.6 & 30.0 \\
$\mathbf{1 0}$ & 24.6 & 18.0 & 26.4 & 33.0 & 30.6 \\
\hline
\end{tabular}

The study site was examined in the thermal band Analysis taken on October 6. 2017. The minimum $20.6^{\circ} \mathrm{C}$, maximum $28.8^{\circ} \mathrm{C}$ is measured for open areas is and a total surface temperature difference is $8.2^{\circ} \mathrm{C}$. For forests surface temperature is minimum $12.6^{\circ} \mathrm{C}$ maximum $30.0^{\circ} \mathrm{C}$ and the temperature difference is $17.4^{\circ} \mathrm{C}$. On water surfaces minimum temperature is $17.4^{\circ} \mathrm{C}$ maximum $28.8^{\circ} \mathrm{C}$ and the total difference is $8.4^{\circ} \mathrm{C}$. 
Surface temperature parameters in agricultural areas; minimum $19.8^{\circ} \mathrm{C}$, maximum of $33.0^{\circ} \mathrm{C}$ and the temperature difference is $13.2^{\circ} \mathrm{C}$. In residential areas, the surface temperature is similar to other land uses; minimum $22.8^{\circ} \mathrm{C}$, maximum $27.0^{\circ} \mathrm{C}$ and the total difference was $4.2^{\circ} \mathrm{C}$ (Table 3 and Figure 5).

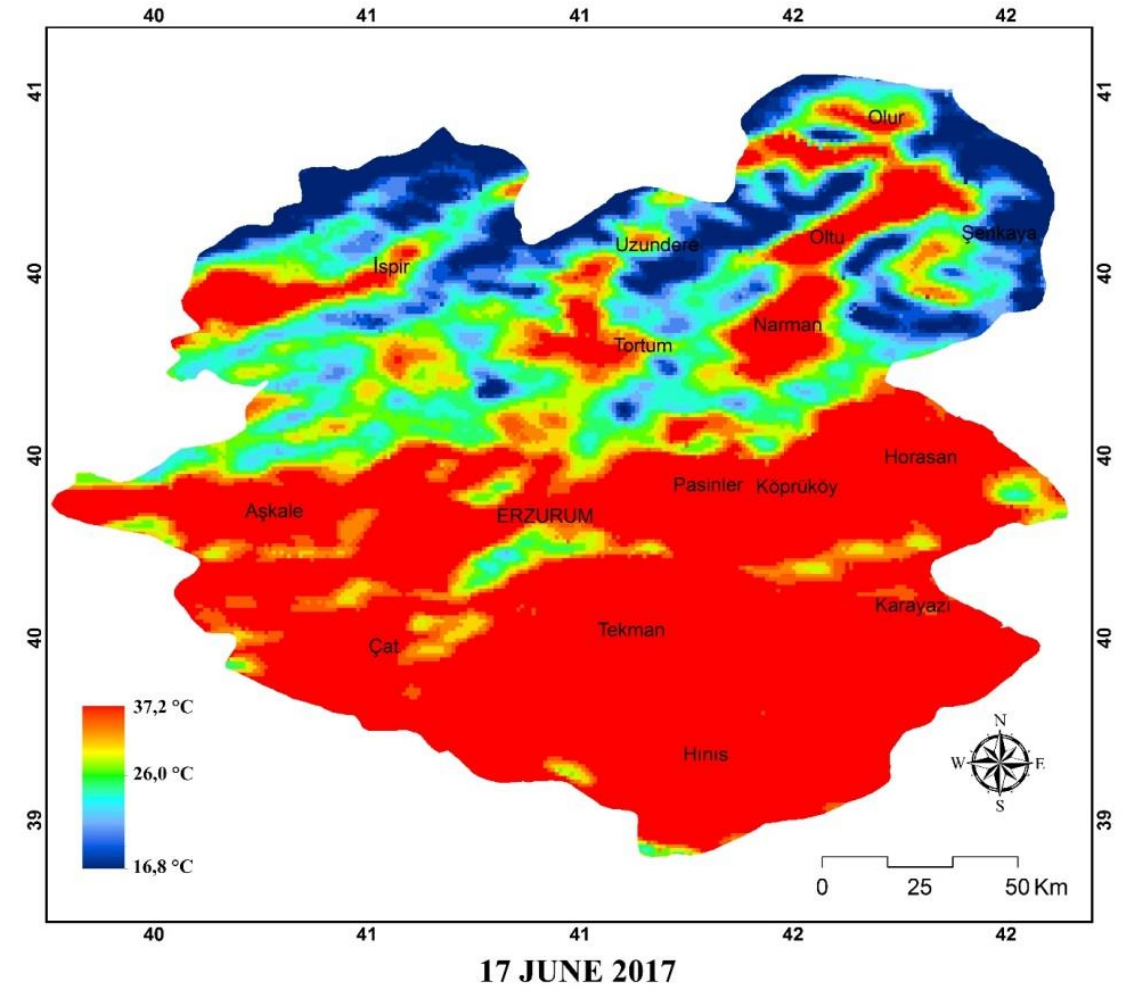

Figure 4. Thermal Band Analysis of the study area on 17 June 2017

Table 3. The values of thermal band analysis results of the study area on 6 October 2017

\begin{tabular}{c|c|c|c|c|c}
\hline Points & $\begin{array}{c}\text { Open Spaces } \\
\left({ }^{\circ} \mathbf{C}\right)\end{array}$ & $\begin{array}{c}\text { Forests } \\
\left({ }^{\circ} \mathbf{C}\right)\end{array}$ & $\begin{array}{c}\text { Water Surfaces } \\
\left({ }^{\circ} \mathbf{C}\right)\end{array}$ & $\begin{array}{c}\text { Agricultural Areas } \\
\left({ }^{\circ} \mathbf{C}\right)\end{array}$ & $\begin{array}{c}\text { Residential Areas } \\
\left({ }^{\circ} \mathbf{C}\right)\end{array}$ \\
\hline $\mathbf{1}$ & 21.6 & 16.2 & 21.6 & 27.0 & 22.2 \\
$\mathbf{2}$ & 23.4 & 18.0 & 20.4 & 26.4 & 24.6 \\
$\mathbf{3}$ & 22.8 & 13.2 & 17.4 & 23.4 & 25.2 \\
$\mathbf{4}$ & 24.6 & 15.6 & 23.4 & 25.8 & 25.8 \\
$\mathbf{5}$ & 28.2 & 19.8 & 25.8 & 25.8 & 24.0 \\
$\mathbf{6}$ & 27.6 & 23.4 & 25.8 & 25.2 & 22.8 \\
$\mathbf{7}$ & 20.4 & 12.6 & 21.6 & 19.8 & 25.2 \\
$\mathbf{8}$ & 24.6 & 30.0 & 24.6 & 25.8 & 24.0 \\
$\mathbf{9}$ & 28.8 & 22.2 & 23.4 & 24.6 & 27.0 \\
$\mathbf{1 0}$ & 22.2 & 13.2 & 22.2 & 33.0 & 25.8 \\
\hline
\end{tabular}

When we examine the thermal band analysis on 2 December 2017; a maximum of $9.8^{\circ} \mathrm{C}$ is observed at open areas sampling points. While a minimum of $-3.5^{\circ} \mathrm{C}$ with a difference of $13.4^{\circ} \mathrm{C}$, a minimum temperature of $-4.1^{\circ} \mathrm{C}$ is determined when a maximum surface temperature of $6.0^{\circ} \mathrm{C}$ in the forest areas. The temperature difference is $10.2^{\circ} \mathrm{C}$. On the water surface, the minimum temperature is $-9.5^{\circ} \mathrm{C}$, maximum $-4.1^{\circ} \mathrm{C}$ and the 
total difference is $5.4^{\circ} \mathrm{C}$. For the agricultural areas a minimum temperature is $-4.7^{\circ} \mathrm{C}$ and a maximum temperature $9.0^{\circ} \mathrm{C}$. The total temperature difference in agricultural areas is $13.8^{\circ} \mathrm{C}$. In the same way, the minimum surface temperature of the residential area is $-7.75^{\circ} \mathrm{C}$, maximum surface temperature is $6.0^{\circ} \mathrm{C}$ and the difference is $13.8^{\circ} \mathrm{C}$ (Table 4 and Figure 6).

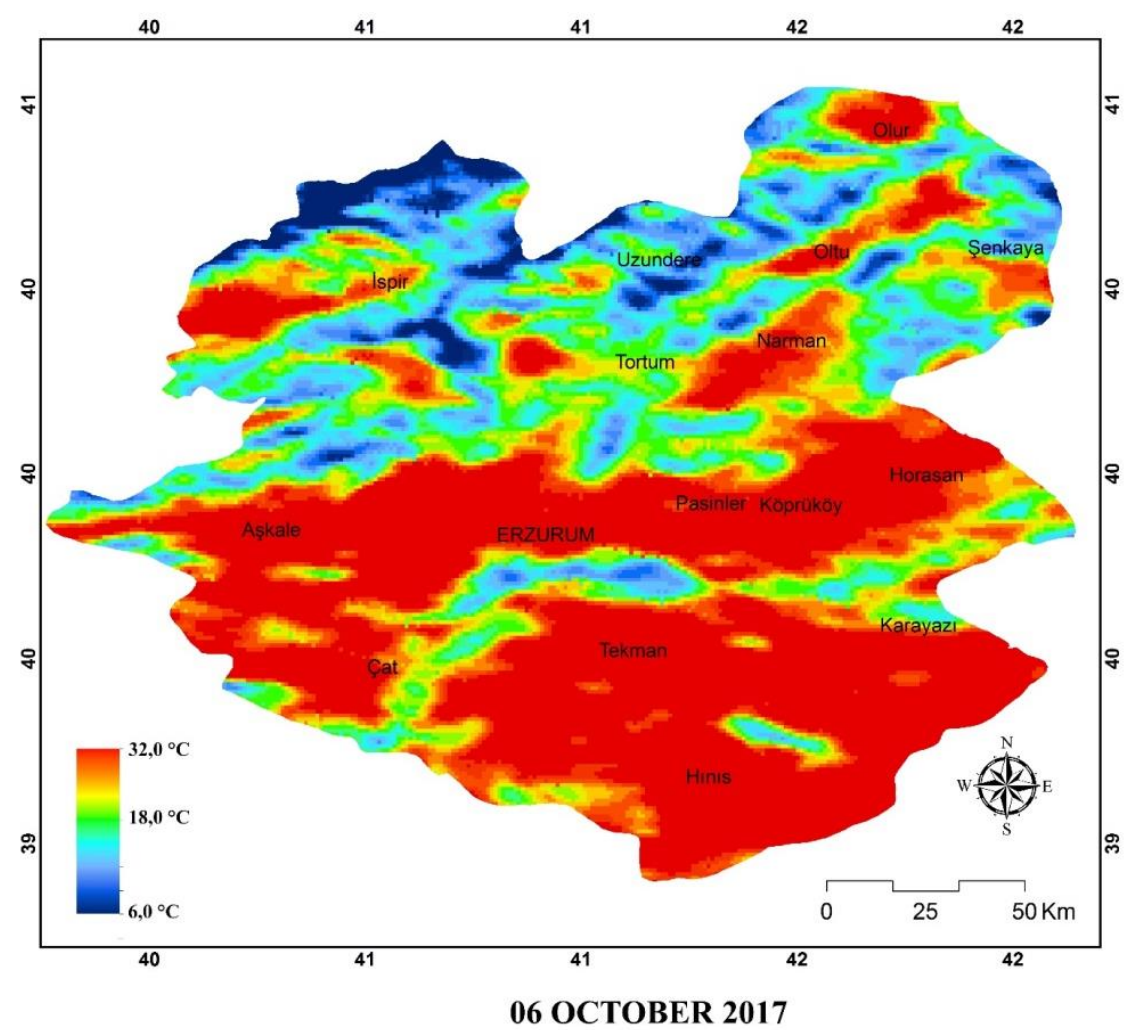

Figure 5. Thermal band analysis of the study area on 6 October 2017

Table 4. The values of thermal band analysis results of the study area on 2 December 2017

\begin{tabular}{c|c|c|c|c|c}
\hline Points & $\begin{array}{c}\text { Open Spaces } \\
\left({ }^{\circ} \mathbf{C}\right)\end{array}$ & $\begin{array}{c}\text { Forests } \\
\left({ }^{\circ} \mathbf{C}\right)\end{array}$ & $\begin{array}{c}\text { Water Surfaces } \\
\left({ }^{\circ} \mathbf{C}\right)\end{array}$ & $\begin{array}{c}\text { Agricultural Areas } \\
\left({ }^{\circ} \mathbf{C}\right)\end{array}$ & $\begin{array}{c}\text { Residential Areas } \\
\left({ }^{\circ} \mathbf{C}\right)\end{array}$ \\
\hline $\mathbf{1}$ & 4.2 & 3.0 & -4.1 & -2.9 & -0.5 \\
$\mathbf{2}$ & -2.9 & 2.4 & 6.6 & -2.9 & 6.0 \\
$\mathbf{3}$ & 9.8 & -1.7 & -1.7 & -3.5 & 4.2 \\
$\mathbf{4}$ & -0.5 & 2.4 & -9.5 & -1.1 & -2.3 \\
$\mathbf{5}$ & -0.5 & -4.1 & 7.2 & 1.2 & 5.4 \\
$\mathbf{6}$ & 6.6 & -0.5 & 2.4 & 5.4 & 6.6 \\
$\mathbf{7}$ & -3.5 & 0.6 & -5.3 & -4.7 & 0.0 \\
$\mathbf{8}$ & -2.3 & 6.0 & -2.3 & -2.3 & 6.0 \\
$\mathbf{9}$ & 5.4 & -2.3 & 4.2 & 2.4 & -2.3 \\
$\mathbf{1 0}$ & -1.1 & 0.0 & -2.3 & 9.0 & -7.7 \\
\hline
\end{tabular}

When we examined the thermal band images on the basin scale on December 22017 ; Erzurum Province is covered with snow cover in general. However, the thermal band analyses show in areas where there is little or no snow cover. The surface temperature is 
higher than other areas (Figure 6). Coruh Basin has a lot of elevation differences in terms of topographic properties. Therefore, there are some formations of micro-climatic areas due to these characteristics. Micro-climatic areas are seen to be warmer in terms of surface temperature. On the other hand, Aras Basin and Firat-Dicle basin consist of very flat areas in terms of topography. Flat areas are very cold because they are covered with snow cover in terms of surface temperature. However, in some rugged areas of the Aras Basin. The surface temperature is partly warmer than other areas (Figure 6).

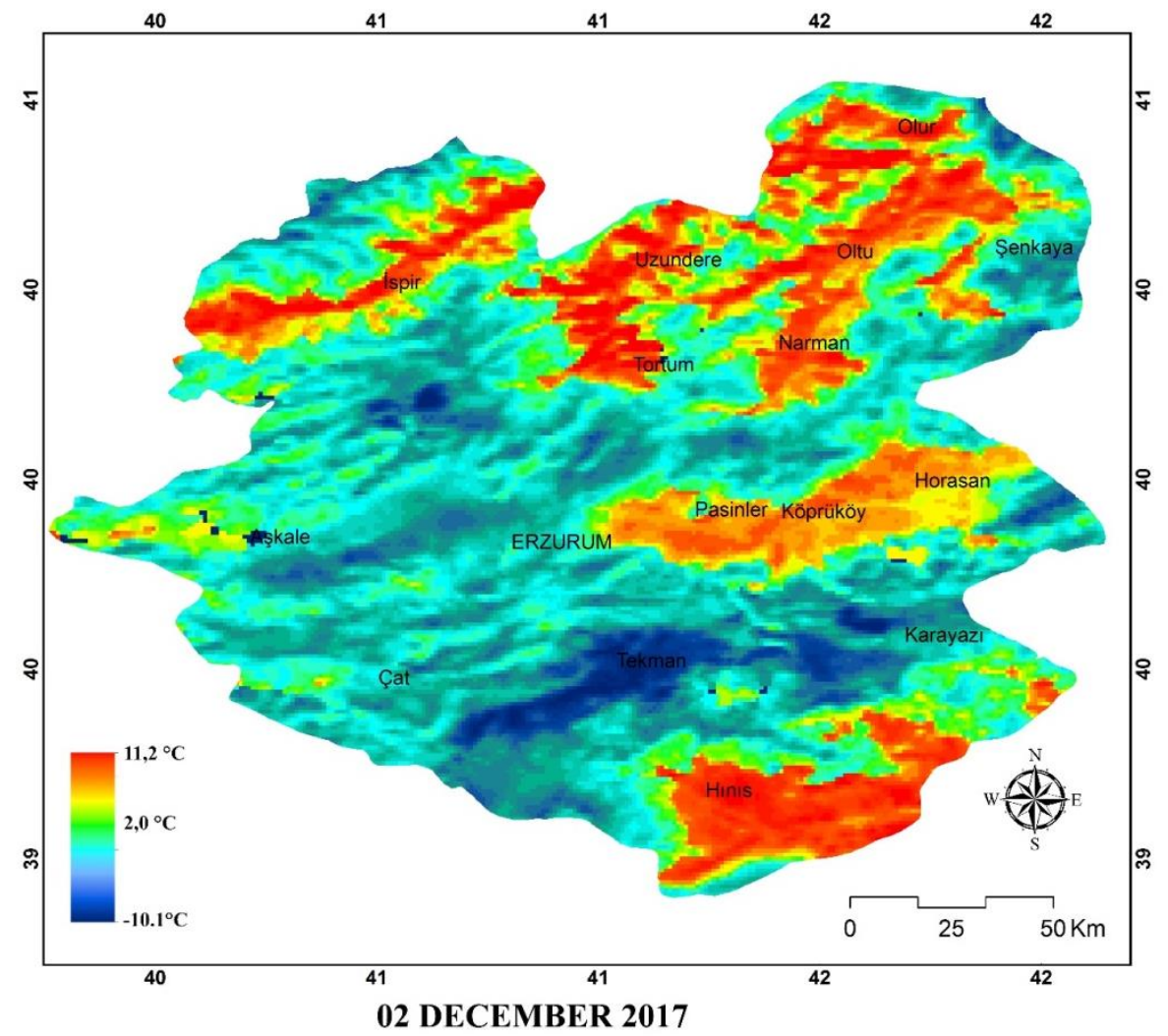

Figure 6. Thermal band analysis of the study area on 2 December 2017

In the study area, sampling points were obtained from 10 different locations, homogeneously distributed for each different land use. MODIS satellite sensors with a spatial resolution of $1000 \mathrm{~m}$ cause a large standard deviation in small areas. Therefore, while obtaining the data, sampling area was considered. The sampling areas sizes ranges from $2.3 \mathrm{~km}^{2}$ to $14 \mathrm{~km}^{2}$. The areas are not smaller than $1 \mathrm{~km}^{2}$; hence it resulted in low standard deviation of LST data from the MODIS satellite sensors. In addition, the thermal data was obtained from the 4 different stations of the General Directorate of Meteorology Affairs for the accuracy of the sensor data used in the study (Table 5). On the basis of the resulting data, the difference of average surface temperature between stations was $1.9^{\circ} \mathrm{C}$.

In the statistical analysis of this study, the effects of land use, month, and altitude were examined from the factors affecting the surface temperature. Because month and land use factors used as categorical, altitude factor used as continuous variables, CHAID analysis was preferred, which is a method use both categorical and continuous 
variables. Beside this, the values of the altitude continuous variable divided into homogenous subgroups are automatically performed.

Table 5. Temperature values obtained from thermal band analysis and meteorology stations

\begin{tabular}{c|c|c|c|c|c}
\hline \multicolumn{2}{c|}{ Date/Place } & $\begin{array}{c}\text { 4 Apr 2017 } \\
\left({ }^{\circ} \mathbf{C}\right)\end{array}$ & $\begin{array}{c}\text { 17 Jun 2017 } \\
\left({ }^{\circ} \mathbf{C}\right)\end{array}$ & $\begin{array}{c}\text { 6 Oct 2017 } \\
\left({ }^{\circ} \mathbf{C}\right)\end{array}$ & $\begin{array}{c}\text { 2 Dec 2017 } \\
\left({ }^{\circ} \mathbf{C}\right)\end{array}$ \\
\hline \multirow{2}{*}{ İspir } & Radio-meter & 19.6 & 27.2 & 23.8 & 7.9 \\
& Station & 18.4 & 24.9 & 22.9 & 6.7 \\
\hline \multirow{2}{*}{ Erzurum } & Radio-meter & 12.8 & 22.3 & 16.1 & -3.2 \\
& Station & 11.7 & 21.0 & 14.8 & -1.0 \\
\hline \multirow{2}{*}{ Tekman } & Radio-meter & 12.3 & 26.4 & 15.1 & -8.2 \\
& Station & 8.5 & 21.4 & 14.3 & -6.4 \\
\hline \multirow{2}{*}{ Hinıs } & Radio-meter & 12.1 & 24.3 & 18.1 & 5.2 \\
& Station & 10.5 & 21.9 & 16 & 4.9 \\
\hline
\end{tabular}

According to the results of the statistical analysis, the most effective factors on the temperature of the months of June and October formed a homogeneous group in itself, and the temperature average is $23.9^{\circ} \mathrm{C}$. It is determined that the month of December $\left(0.6^{\circ} \mathrm{C}\right)$ with the lowest temperature average has an altitude effect (Figure 7 ).

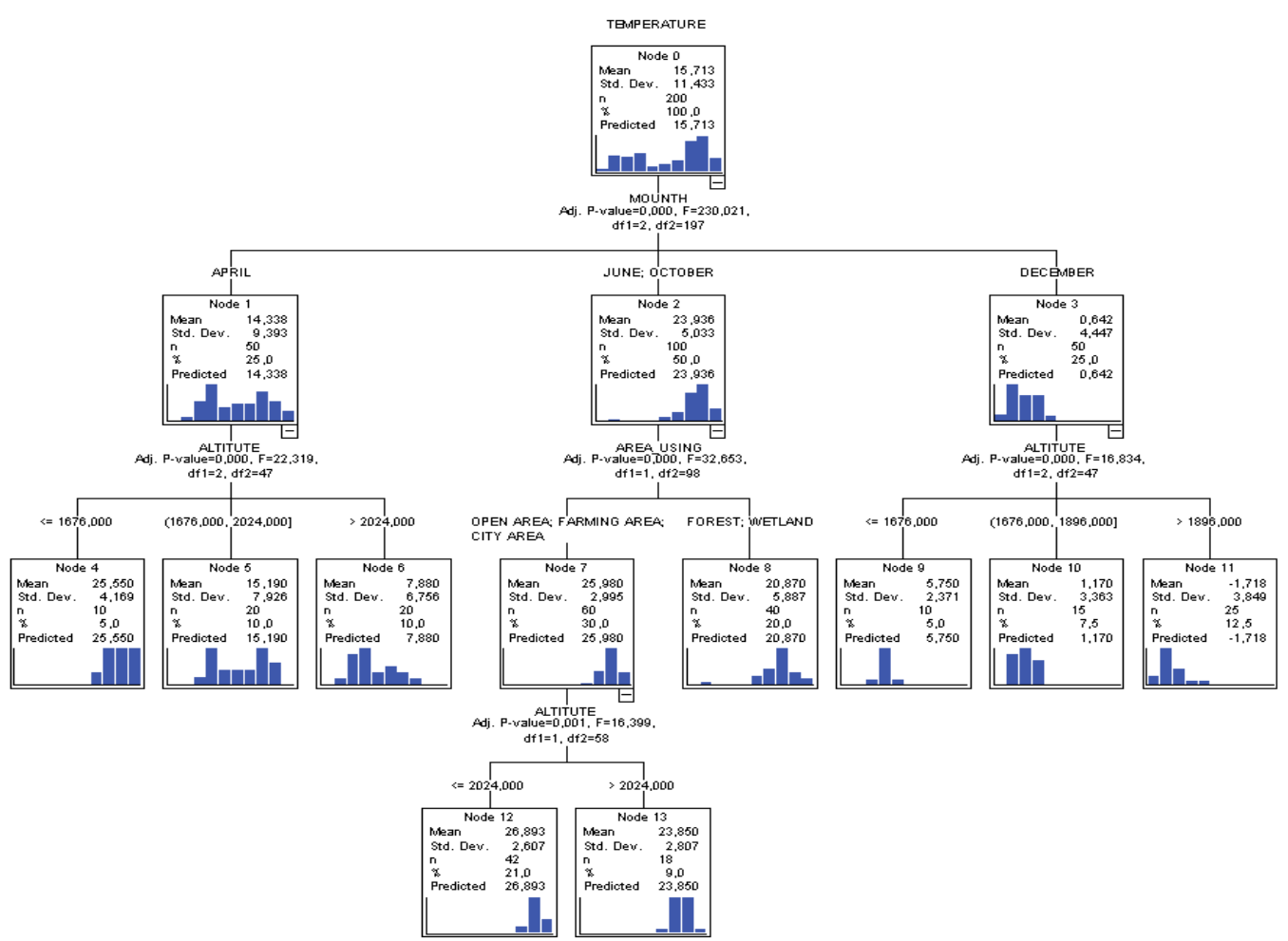

Figure 7. Statistical analysis of thermal band data

The altitude is divided into 3 heterogeneous groups while forming a homogeneous group in itself. While the average temperature of December is $5.7^{\circ} \mathrm{C}$ at a height lower than $1676 \mathrm{~m}$. the temperature is between $1676-1896 \mathrm{~m}$ is $1.1^{\circ} \mathrm{C}$ and the temperature in the altitude above $1896 \mathrm{~m}$ is determined as $-1.1^{\circ} \mathrm{C}$ (Figure 7). 
$\mathrm{P}<0.00$ has been effective in the land uses on the months of June and October. Among all land uses categories, open spaces and residential areas created one group. Forests and water surfaces created another group. Average surface temperature in open areas and residential areas is $25.9^{\circ} \mathrm{C}$. In the other group, the surface temperature of the forest and water surfaces is $20.8^{\circ} \mathrm{C}$ (Figure 7).

The group formed by the open areas, agricultural areas and residential areas has been affected by height and the surface temperature of the area, which is less than $2024 \mathrm{~m}$ in altitude, is $26.89^{\circ} \mathrm{C}$ over $2024 \mathrm{~m}$ is $23.8^{\circ} \mathrm{C}$. In the month of April only altitude was effective. The surface temperature at a height lower than $1676 \mathrm{~m}$ is $25.55^{\circ} \mathrm{C}$, while the temperature is between $1676-2024 \mathrm{~m}$ is $15.1^{\circ} \mathrm{C}$ and over $2024 \mathrm{~m}$ is $7.8^{\circ} \mathrm{C}$ (Figure 7).

Overall, the most effective factor on the surface temperature was the month which comprise June, October, April and December. June and October were creating a homogeneous sub-group with the average surface temperature $23.9^{\circ} \mathrm{C}$. On the other hand, April with a range of $14.3^{\circ} \mathrm{C}$ and December with a range of $0.6^{\circ} \mathrm{C}$ were creating separate group. The highest average surface temperature was seen at node 12 . On this node, the average surface temperature obtained from 42 different observation points when open areas, farming areas and city areas and the altitude were lower than $2024 \mathrm{~m}$ for June and October as $26.9^{\circ} \mathrm{C}$.

\section{Discussion}

One of the biggest problems facing seasonal determination of surface temperature is to distinguish between seasonal and sudden changes (Verbesselt et al., 2010; Ghazaryan et al., 2016; Muro et al., 2018). As a matter of fact seasonal timelines are divided into consideration of the 1-year urban meteorology data of 2017. It is also stated in previous studies that the measured value between 2 different single points to determine the surface temperature change is not an ecological indication (McVicar and Jupp, 1998). This study was evaluated by taking 10 different points in 5 different categories in 4 different time intervals on the province-scale. Surface temperature is used as an ideal tool for temporal analysis in the basin and other scales. although the resolution of the MODIS satellite in thermal band analyses is low quality (Neteler. 2010).

The reason for the selection of Chaid analysis in this study is that two of the arguments (land use and month) are categorical and one (altitude) is a constant variable. The determination coefficient between the temperature values observed and the expected temperature values $\left(\mathrm{R}^{2}\right)$ was calculated as 0.82 . In another similar study the value of correlation between the two variables $\left(\mathrm{R}^{2}\right)$ was calculated as 0.65 (Muro et al., 2018).

Areas with the highest average surface temperature in the study site were determined as residential areas and they had a surface temperature of $18.7^{\circ} \mathrm{C}$. At the same time the forest surfaces $12.2^{\circ} \mathrm{C}$ water surfaces $13.8^{\circ} \mathrm{C}$ agricultural areas $17.9^{\circ} \mathrm{C}$ and open areas $15.7^{\circ} \mathrm{C}$ were determined to have an average surface temperature. When the bonding between land uses and average surface temperatures is examined an average surface temperature difference was observed as $3.4^{\circ} \mathrm{C}$ between open areas and forests. Similarly, in previous studies, this difference was between 12 and $1.8^{\circ} \mathrm{C}$ (Falahatkar et al., 2011; Li et al., 2012; Mallick et al., 2012). In some studies, the difference between water surfaces and forests temperatures was found to be less important (Van and Bao, 2016). Indeed, in this study surface temperature values were close to each other in the water surfaces and forests. However, in another group study the difference between the 
forests and water surface temperatures was observed over $10^{\circ} \mathrm{C}$ (Falahatkar et al., 2011). In different studies the causes of different surface temperatures in similar land uses are topographic status of land structure, change in land use and humidity (Yuksel and Yilmaz, 2008). In this study, we have done on the provincial scale accommodates within the boundaries of 3 different basins. Even on the inside of these basins the land heights and climatic conditions are constantly differentiating from each other. Therefore, it causes different surface temperature values in the same land use.

\section{Conclusion}

In our study, we investigated the link between different land surface covers and surface temperature (LST) statistically. As a matter of fact, in the scientific studies that were made before, the method of statistical multi-linear regression analysis and correlation calculations were used for determining links between land surface temperature and land use (Choudhury et al., 2018; Wang et al., 2018). The point that makes our study different from other studies; we have been annotated with CHAID analysis by adding height and 4 different time zones in order to determine links between land surface temperature and land use. The reason for choosing CHAID analysis is that the month and land use factors used as the categorical variables, and the altitude factor used as continuous variables. In addition, using thermal band images in different time periods has supported the consistency of the links between LST and the land use.

In this study, Erzurum Province located in the eastern part of Turkey were investigated and also the 3 basin examples within the provincial boundaries were discussed. According to the results of the statistical analysis of the study, the most effective factor on surface temperature is the month of June and October in which a homogeneous group and the temperature average of this group is $23.9^{\circ} \mathrm{C}$. It is determined that the month of December $\left(0.64^{\circ} \mathrm{C}\right)$ with the lowest temperature average has an altitude effect.

If we look at the land use categories, the average surface temperature in the open areas and residential areas is $25.9^{\circ} \mathrm{C}$. in the other group, the surface temperature of the forests and water surfaces is $20.8^{\circ} \mathrm{C}$. When we discussed the study results in the basin scale, the surface temperature was higher at Coruh basin than Aras and Dicle basin due to altidute.

In addition, the results of this study can be used as a preliminary study in the planning activities for the future basin planning, urban planning, water resources conservation and uses and the planning of nature conservation.

\section{REFERENCES}

[1] Akin, M., Eyduran, E., Reed, B. M. (2017): Use of RSM and CHAID data mining algorithm for predicting mineral nutrition of hazelnut. - Plant Cell Tissue and Organ Culture 128(2): 317-317.

[2] Alexander, L. V., Zhang, X., Peterson, T. C., Caesar, J., Gleason, B., Tank, A. M. G. K., Haylock, M., Collins, D., Trewin, B., Rahimzadeh, F., Tagipour, A., Kumar, K. R., Revadekar, J., Griffiths, G., Vincent, L., Stephenson, D. B., Burn, J., Aguilar, E., Brunet, M., Taylor, M., New, M., Zhai, P., Rusticucci, M., Vazquez-Aguirre, J. L. (2006): Global observed changes in daily climate extremes of temperature and precipitation. - Journal of Geophysical Research-Atmospheres 111(D5). 
[3] Arnfield, A. J. (2003): Two decades of urban climate research: A review of turbulence. exchanges of energy and water. and the urban heat island. - International Journal of Climatology 23(1): 1-26.

[4] Becker, F., Li, Z. L. (1990): Towards a Local Split Window Method over Land Surfaces. - International Journal of Remote Sensing 11(3): 369-393.

[5] Becker, A., Inoue, S., Fischer, M., Schwegler, B. (2012): Climate change impacts on international seaports: knowledge. perceptions. and planning efforts among port administrators. - Climatic Change 110(1-2): 5-29.

[6] Blasi, M. G., Liuzzi, G., Masiello, G., Serio, C., Telesca, V., Venafra, S. (2016): Surface parameters from SEVIRI observations through a Kalman filter approach: application and evaluation of the scheme in Southern Italy. - Tethys-Journal of Mediterranean Meteorology \& Climatology (13): 3-10.

[7] Chen, Y. H., Zhan, W. F., Quan, J. L., Zhou, J., Zhu, X. L., Sun, H. (2014): Disaggregation of Remotely Sensed Land Surface Temperature: A Generalized Paradigm. - Ieee Transactions on Geoscience and Remote Sensing 52(9): 5952-5965.

[8] Cho, K., Kim, Y., Kim, Y. (2018): Disaggregation of Landsat-8 Thermal Data Using Guided SWIR Imagery on the Scene of a Wildfire. - Remote Sensing 10(1).

[9] Choudhury, D., Das, K., Das, A. (2018): Assessment of land use land cover changes and its impact on variations of land surface temperature in Asansol-Durgapur Development Region. - The Egyptian Journal of Remote Sensing and Space Science.

[10] Chrysoulakis, N., Lopes, M., San Jose, R., Grimmond, C. S. B., Jones, M. B., Magliulo, V., Klostermann, J. E. M., Synnefa, A., Mitraka, Z., Castro, E. A., Gonzalez, A., Vogt, R., Vesala, T., Spano, D., Pigeon, G., Freer-Smith, P., Staszewski, T., Hodges, N., Mills, G., Cartalis, C. (2013): Sustainable urban metabolism as a link between bio-physical sciences and urban planning: The BRIDGE project. - Landscape and Urban Planning 112: 100-117.

[11] Eastman, J. (2001): IDRISI 32 release 2. guide to GIS and image processing volumes 1 and 2. - Clark Labs. Clark University. Worcester.

[12] El-Khoury, A., Seidou, O., Lapen, D. R., Que, Z., Mohammadian, M., Sunohara, M., Bahram, D. (2015): Combined impacts of future climate and land use changes on discharge. nitrogen and phosphorus loads for a Canadian river basin. - Journal of Environmental Management 151: 76-86.

[13] Falahatkar, S., Hosseini, S. M., Soffianian, A. R. (2011): The relationship between land cover changes and spatial-temporal dynamics of land surface temperature. - Indian Journal of Science and Technology 4(2): 76-81.

[14] Fearnside, P. M. (2015): Emissions from tropical hydropower and the IPCC. Environmental Science \& Policy 50: 225-239.

[15] Felzer, B. S. (2012): Carbon. nitrogen. and water response to climate and land use changes in Pennsylvania during the 20th and 21st centuries. - Ecological Modelling 240: 49-63.

[16] Feng, M., Sexton, J. O., Huang, C. Q., Masek, J. G., Vermote, E. F., Gao, F., Narasimhan, R., Channan, S., Wolfe, R. E., Townshend, J. R. (2013): Global surface reflectance products from Landsat: Assessment using coincident MODIS observations. - Remote Sensing of Environment 134: 276-293.

[17] Feng, X., Myint, S. W. (2016): Exploring the effect of neighboring land cover pattern on land surface temperature of central building objects. - Building and Environment 95: 346-354.

[18] Gallego-Elvira, B., Taylor, C. M., Harris, P. P., Ghent, D., Veal, K. L., Folwell, S. S. (2016): Global observational diagnosis of soil moisture control on the land surface energy balance. - Geophysical Research Letters 43(6): 2623-2631.

[19] Ghazaryan, G., Dubovyk, O., Kussul, N., Menz, G. (2016): Towards an Improved Environmental Understanding of Land Surface Dynamics in Ukraine Based on MultiSource Remote Sensing Time-Series Datasets from 1982 to 2013. - Remote Sensing 8(8). 
[20] Gonzalez, A., Donnelly, A., Jones, M., Chrysoulakis, N., Lopes, M. (2013): A decisionsupport system for sustainable urban metabolism in Europe. - Environmental Impact Assessment Review 38: 109-119.

[21] Imhoff, M. L., Zhang, P., Wolfe, R. E., Bounoua, L. (2010): Remote sensing of the urban heat island effect across biomes in the continental USA. - Remote Sensing of Environment 114(3): 504-513.

[22] İT, L. B. (2004): CORINE Arazi Kullan ımı Sinıflandırma Sistemine Göre Arazi Kullanım Haritasının Hazırlanması: Isparta Örneği. - TARIM BILIMLERI DERGISI 10(4): 366-374.

[23] Jacob, F., Petitcolin, F., Schmugge, T., Vermote, E., French, A., Ogawa, K. (2004): Comparison of land surface emissivity and radiometric temperature derived from MODIS and ASTER sensors. - Remote Sensing of Environment 90(2): 137-152.

[24] Justice, C. O., Townshend, J. R. G., Vermote, E. F., Masuoka, E., Wolfe, R. E., Saleous, N., Roy, D. P., Morisette, J. T. (2002): An overview of MODIS Land data processing and product status. - Remote Sensing of Environment 83(1-2): 3-15.

[25] Li, Y. Y., Zhang, H., Kainz, W. (2012): Monitoring patterns of urban heat islands of the fast-growing Shanghai metropolis. China: Using time-series of Landsat TM/ETM+ data. - International Journal of Applied Earth Observation and Geoinformation 19: 127-138.

[26] Li, Z. L., Tang, B. H., Wu, H., Ren, H. Z., Yan, G. J., Wan, Z. M., Trigo, I. F., Sobrino, J. A. (2013): Satellite-derived land surface temperature: Current status and perspectives. Remote Sensing of Environment 131: 14-37.

[27] Mallick, J., Kant, Y., Bharath, B. (2008): Estimation of land surface temperature over Delhi using Landsat-7 ETM+. - J. Ind. Geophys. Union 12(3): 131-140.

[28] Mallick, J., Singh, C. K., Shashtri, S., Rahman, A., Mukherjee, S. (2012): Land surface emissivity retrieval based on moisture index from LANDSAT TM satellite data over heterogeneous surfaces of Delhi city. - International Journal of Applied Earth Observation and Geoinformation 19: 348-358.

[29] Masiello, G., Serio, C., Venafra, S., Liuzzi, G., Gottsche, F., Trigo, I. F., Watts, P. (2015): Kalman filter physical retrieval of surface emissivity and temperature from SEVIRI infrared channels: a validation and intercomparison study. - Atmospheric Measurement Techniques 8(7): 2981-2997.

[30] McVicar, T. R., Jupp, D. L. B. (1998): The current and potential operational uses of remote sensing to aid decisions on drought exceptional circumstances in Australia: a review. - Agricultural Systems 57(3): 399-468.

[31] Montvay, I., Pietarinen, E. (1982): The Stefan Boltzmann Law at High-Temperature for the Gluon Gas. - Physics Letters B 110(2): 148-154.

[32] Muro, J., Strauch, A., Heinemann, S., Steinbach, S., Thonfeld, F., Waske, B., Diekkruger, B. (2018): Land surface temperature trends as indicator of land use changes in wetlands. - International Journal of Applied Earth Observation and Geoinformation 70: 62-71.

[33] Narimanov, E. E., Smolyaninov, I. I. (2012): Beyond Stefan-Boltzmann Law: Thermal Hyper-Conductivity. - 2012 Conference on Lasers and Electro-Optics (Cleo).

[34] Neteler, M. (2010): Estimating Daily Land Surface Temperatures in Mountainous Environments by Reconstructed MODIS LST Data. - Remote Sensing 2(1): 333-351.

[35] Prata, A., Caselles, V., Coll, C., Sobrino, J., Ottle, C. (1995): Thermal remote sensing of land surface temperature from satellites: Current status and future prospects. - Remote Sensing Reviews 12(3-4): 175-224.

[36] Rajczak, J., Schar, C. (2017): Projections of Future Precipitation Extremes Over Europe: A Multimodel Assessment of Climate Simulations. - Journal of Geophysical ResearchAtmospheres 122(20): 10773-10800.

[37] Rawat, K. S., Sehgal, V., Ray, S. (2018): Downscaling of MODIS thermal imagery. The Egyptian Journal of Remote Sensing and Space Science. 
[38] Rosas, J., Houborg, R., McCabe, M. F. (2017): Sensitivity of Landsat 8 Surface Temperature Estimates to Atmospheric Profile Data: A Study Using MODTRAN in Dryland Irrigated Systems. - Remote Sensing 9(10).

[39] Schott, J. R., Hook, S. J., Barsi, J. A., Markham, B. L., Miller, J., Padula, F. P., Raqueno, N. G. (2012): Thermal infrared radiometric calibration of the entire Landsat 4, 5, and 7 archive (1982-2010). - Remote Sensing of Environment 122: 41-49.

[40] Seung-Hwan, Y., Jin-Yong, C., Sang-Hyun, L., Yun-Gyeong, O., Koun, Y. D. (2013): Climate change impacts on water storage requirements of an agricultural reservoir considering changes in land use and rice growing season in Korea. - Agricultural Water Management 117: 43-54.

[41] Song, J., Wang, Z. H., Myint, S. W., Wang, C. Y. (2017): The hysteresis effect on surface-air temperature relationship and its implications to urban planning: An examination in Phoenix. Arizona. USA. - Landscape and Urban Planning 167: 198-211.

[42] Streutker, D. R. (2003): Satellite-measured growth of the urban heat island of Houston, Texas. - Remote Sensing of Environment 85(3): 282-289.

[43] Tomlinson, C. J., Chapman, L., Thornes, J. E., Baker, C. J. (2012): Derivation of Birmingham's summer surface urban heat island from MODIS satellite images. International Journal of Climatology 32(2): 214-224.

[44] Tong, S. T. Y., Sun, Y., Ranatunga, T., He, J., Yang, Y. J. (2012): Predicting plausible impacts of sets of climate and land use change scenarios on water resources. - Applied Geography 32(2): 477-489.

[45] Tran, T. V., Ha, D. X. B. (2008): A study on urban development through land surface temperature by using remote sensing: in case of Ho Chi Minh City. - VNU Journal of Science 24: 160-167.

[46] van der Knaap, Y. A., Bakker, M. M., Alam, S. J., Witte, J.-P. M., Aerts, R., van Ek, R., van Bodegom, P. M. (2018): Projected vegetation changes are amplified by the combination of climate change. socio-economic changes and hydrological climate adaptation measures. - Land Use Policy 72: 547-562.

[47] van Haren, R., van Oldenborgh, G. J., Lenderink, G., Collins, M., Hazeleger, W. (2013): SST and circulation trend biases cause an underestimation of European precipitation trends. - Climate Dynamics 40(1-2): 1-20.

[48] Van, T. T., Bao, H. D. X. (2016): A study on urban development through land surface temperature by using remote sensing: in case of Ho Chi Minh City. - VNU Journal of Science: Earth and Environmental Sciences 24(3).

[49] Verbesselt, J., Hyndman, R., Newnham, G., Culvenor, D. (2010): Detecting trend and seasonal changes in satellite image time series. Remote Sensing of Environment 114(1): 106-115.

[50] Voogt, J. A., Oke, T. R. (2003): Thermal remote sensing of urban climates. - Remote Sensing of Environment 86(3): 370-384.

[51] Wang, Y. C., Hu, B. K. H., Myint, S. W., Feng, C. C., Chow, W. T. L., Passy, P. F. (2018): Patterns of land change and their potential impacts on land surface temperature change in Yangon, Myanmar. - Science of the Total Environment 643: 738-750.

[52] Weng, Q. H. (2009): Thermal infrared remote sensing for urban climate and environmental studies: Methods. applications. and trends. - Isprs Journal of Photogrammetry and Remote Sensing 64(4): 335-344.

[53] Wu, L., Long, T. Y., Liu, X., Guo, J. S. (2012): Impacts of climate and land-use changes on the migration of non-point source nitrogen and phosphorus during rainfall-runoff in the Jialing River Watershed. China. - Journal of Hydrology 475: 26-41.

[54] Xia, L., Zhao, F., Chen, L., Zhang, R., Mao, K., Kylling, A., Ma, Y. (2018): Performance comparison of the MODIS and the VIIRS $1.38 \mu \mathrm{m}$ cirrus cloud channels using libRadtran and CALIOP data. - Remote Sensing of Environment 206: 363-374. 
[55] Yang, X. Y., Li, Y. G., Yang, L. N., (2012): Predicting and understanding temporal 3D exterior surface temperature distribution in an ideal courtyard. - Building and Environment 57: 38-48.

[56] Yildiz, N. D., Avdan, U., Yilmaz, S., Matzarakis, A. (2018): Thermal map assessment under climate and land use changes; a case study for Uzundere Basin. - Environmental Science and Pollution Research 25(1): 940-951.

[57] Yuksel, U. D., Yilmaz, O. (2008): A study on determining and evaluating summertime urban heat İslands in Ankara at regional and local scale utilizing remote sensing and meteorological data. - Journal of the Faculty of Engineering and Architecture of Gazi University 23(4): 937-952.

[58] Zhan, W. F., Chen, Y. H., Zhou, J., Li, J., Liu, W. Y. (2011): Sharpening Thermal Imageries: A Generalized Theoretical Framework From an Assimilation Perspective. Ieee Transactions on Geoscience and Remote Sensing 49(2): 773-789.

[59] Zhang, X. Y., Friedl, M. A., Schaaf, C. B., Strahler, A. H. (2004): Climate controls on vegetation phenological patterns in northern mid- and high latitudes inferred from MODIS data. - Global Change Biology 10(7): 1133-1145. 